\title{
THE USE OF UNDISCLOSED EVIDENCE BY GOVERNMENT OFFICIALS IN ADMINISTRATIVE AND JUDICIAL PROCEEDINGS
}

Historically, the maim check on arbitrary action by administrators and courts has been to require that the aggrieved party have (1) an opportunity to rebut or explain evidence against him, and (2) an opportunity for review to ensure that a justifiable decision was reached. But im recent years there has been an increasing use of undisclosed information as the basis for administrative and judicial actions. The extent of this use is suggested by several illustrations.

In 1951 Ignatz Mezei, an alien returning to this country after a 19-month visit in Europe, sought readmission to rejoin his family in Buffalo, New York, where they had previously resided for some 25 years. Upon arrival in New York City, he was temporarily denied permission to enter by an immigration official and was ordered detamed on Ellis Island. Several months later the denial was made permanent by order of Attorney General McGrath. Two years later the Supreme Court reviewed Mezei's predicament. ${ }^{1}$ During all that time he had been detained on Ellis Island-unable to enter the United States and unable to leave because no other country would take him. ${ }^{2}$ His plea inevitably posed the question: why am I being detained? The denial stated that he represented a threat to national security, but the basis of this determination was not revealed. His plea was unsuccessful, however, for the Court held the denial proper, relying on the rubric that an entering alien is entitled to no constitutional protections. ${ }^{3}$

The same treatment is accorded resident aliens after they have been ordered deported. Thus in 1952 Cecil Jay was ordered deported because he had been a inember of the Communist Party from 1935 to 1940 . He came to this country from England in 1914 and remained here except for a period during the first World War when he was serving with the Canadian Army. After the order for deportation had been entered, he applied for its suspension as authorized by the Immigration and Nationality Act of 1953.4 A special inquiry officer found that Jay satisfied all the statutory prerequisites for suspension: he had been present for ten consecutive years since the ground for deportation arose; he was a person of good moral character; and he would suffer extreme and unusual hardship if deported. But the officer decided that the case for suspension did not "warrant favourable action" in view of certain "confidential information".5 On review the Supreme Court affirmed the demial and held that this use of undisclosed information did not violate due process. ${ }^{6}$

Of even greater impact is the government's loyalty-security program, as applied to both government and private employees. ${ }^{7}$ In Bailey v. Richardson, ${ }^{8}$ which

1 Shaughnessy v. Mezei, 345 U.S. 206 (1953).

$27 d$. at 209.

${ }^{3}$ See, e.g., Knauff v. Shaughnessy, 338 U.S. 537, 544 (1950).

466 STAT. 214 (1952), 8 U.S.C. \& 1254 (1953).

5 Jay v. Boyd, 351 U.S. 345,349 (1956). The non-disclosure was based upon a regulation of the Attorney General which provided that "the determination [of the suspension of deportation] ... may be predicated upon confidential information without the disclosure thereof to the applicant, if in the opinion of the officer or the Board making the determination, the disclosure of such information would be prejudicial to the public interest, safety, or security." 8 C.F.R. $\$ 244.3$ (1953).

6 Jay v. Boyd, 351 U.S. 345 (1956).

7 It has been reported that over five million federal employees, five million military personnel, three million executives and employees of private plants with defense contracts, one- 
is still the leading case, the Supreme Court upheld the discharge of a government employee based upon information not disclosed to the employee. Miss Bailey was charged with attendance at unidentified Communist meetings but was denied any information as to those meetings or the identity of those who had given the information. The Board, "after considering all the evidence, includimg confidential reports of the Federal Bureau of Investigation" containimg unsworn accusations by unnamed informants whose reliability was admittedly unknown to the Board itself, ${ }^{\circ}$ found that reasonable grounds existed to believe her disloyal. The lower court held that it was not improper for the Board to rest its decision on undisclosed evidence, on the theory that a government employee is not entitled to know the adverse evidence in a discharge proceeding. The judgment was affirmed by an equally divided Supreme Court without opmion. ${ }^{10}$

While the Bailey case involved "security" information, apparently it is not essential that there be security reasons for non-disclosure. In Ellmore v. Brucker, ${ }^{11}$ a civil service employee was involuntarily retired on grounds of total medical disability. He submitted letters from three physicians expressing that in their opinion le "is not suffering from a type or degree of physical or mental disability which would prevent him from carrying out the duties" of his job, ${ }^{12}$ and requested access to the inedical reports on which the Civil Service Commission was relying. The Commission refused his request on the authority of a regulation ${ }^{13}$ which allowed disclosure only where it was determined that disclosure would not be injurious to the physical or mental health of the employee. ${ }^{14}$

Similar problems arise in connection with the loyalty-security program as it is applied to private employees working under government contracts which involve confidential, secret, or top secret projects. One of the cases reported by Mr. Yarmolinslky, ${ }^{15}$ for example, concerned an employee of a defense plant. The issue before the security board was whether he had completely disassociated limself from the Communist Party. At the hearing, he presented affidavits and testimony to rebut the charge that he had been "rehiably reported" to have continued to promote the Communist Party line after lis alleged disassociation. The government presented no witnesses and refused to disclose the source of the reports. Clearance was denied without a statenient of reasons. ${ }^{16}$

half a million scientists and employees of the AEC, and one-half a million seamen and portworkers have been subjected to the security clearance program. U.S. News \& World Report, Nov. 25,1955, p. 82 . The extent to which undisclosed evidence is used as a basis for decision is unknown, but several indications inay be drawn from situations collected in YaRMolmskY, Case Studies in Personnel Securtity (1955).

8182 F.2d 46 (D.C. Cir. 1950), aff'd per curium by an equally divided court, 341 U.S. 918 (1951).

OId. at 66-67 (dissent).

10341 U.S. 918 (1951).

11236 F.2d 734 (D.C. Cir. 1956).

$12 I d$. at 736 .

135 C.F.R. \& 29.11 (a) (1) \& (2) (1949).

14 But cf. Money v. Anderson, 208 F.2d 34 (D.C. Cir. 1953), where it was held improper to remove a federal employee from classified civil service on charges that he had made improper advances to women employees and teen-age girls without revealing their identity to the employee.

15 Yarmornuskry, Case Studies in Personnel Security 217 (1955).

18 In general, where the employee is denied clearance by the Board, he is sent notice of the charges against him as detailed as security considerations will permit. The employee is also informed of his right to a hearing, which must be granted if requested. INDUSTRIAT PERSONNEL Security Review Programs, 1st Annual Report 25-26 (1956). But note that the cost of this appeal, which is not paid by employers, has been estimated to run from $\$ 1,200$ up, which 


\section{INCIDENCE AND IMIPACT OF USE OF UNDISCLOSED EVIDENCE IN PRESENT PRACTICE}

The above illustrations are examples of situations in which the use of undisclosed information has attained considerable notoriety; but such practices occur in more routine cases too, with differing degrees of success. These may be separated into three groups.

In the first, the government is the plaintiff in a court action to impose civil or criminal sanctions against an individual. United States v. Andolschek, ${ }^{17}$ for example, was a criminal action against certain tax officials for conspiring to violate the tax laws. At the trial defendants requested that certain reports in the government's possession be put into the record. The trial judge excluded these reports because he thought disclosure was forbidden by a treasury regulation. The court of appeals reversed and Judge Learned Hand, speaking for the court, said: "[T]he government must choose; either it must leave the transactions in the obscurity froin which a trial will draw them, or it must expose them fully."18 In these situations, then, it is well established that the government must reveal all the evidence forming the basis of the prosecution or else be denied the action.

In contrast are cases where defendant is prosecuted following an administrative determination in which undisclosed evidence was employed. In United States $v$. Nugent ${ }^{\mathbf{1 9}}$ the defendant was charged with failure to submit to induction into the armed forces. His request for classification as a conscientious objector had earlier been denied following an administrative hearing which, he contended, was improper in that he was not informed of the evidence upon which the denial was based. The Court upheld the convictions and declared that the registrant had no right to see the adverse evidence; the only duty of the administrator was to supply the registrant with a fair résumé of the adverse evidence. ${ }^{20}$

A second situation which presents this problem is that in which the individual brings suit against the government to compel some action alleged to be illegally withheld. Generally, these cases arise after there has been some adverse decision by an administrative agency denying the party's clain. Examples are suits under the Federal Tort Claims Act, ${ }^{21}$ suits under- the Admiralty Acts, ${ }^{22}$ and even certain actions for habeas corpus. ${ }^{23}$ Generally, the courts have refused to allow the gov-

undoubtedly discourages many from availing themselves of this recourse. 8 STAN. L. Rev. 234, $257, \mathrm{n.102}$ (1956). At the hearing, written evidence is not presented to the employee and only rarely does the government present witnesses. Association of THE BAR OF THE CiTY OF NEW York, Tex Federal Loyalty-Security Program 100 (1956). But the Director of the Office of Personnel Security Pohicy has recently stated that "in practice, the Hearing Boards ... urge [witnesses] to appear, and seek to impress upon each of them the importance of his role as a witness." Industrial Personnel Security Review Prooram, 1st Annuat Report 9 (1956).

17142 F.2d 503 (2d Cir. 1944).

18 Id. at 506. Accord, Jencks v. Umited States, 353 U.S. 657 (1957) ; Roviaro v. United States, 353 U.S. 53 (1957); United States v. Grayson, 166 F.2d 863 (2d Cir. 1948); United States v. Beekman, 155 F.2d 580 (2d Cir. 1946). See generally 41 CoRNErL L. Q. 737, 739-41 (1956).

19346 U.S. 1 (1953). Accord, White v. United States, 215 F.2d 782 (9th Cir. 1954).

20346 U.S. at 6.

21 United States v. Reynolds, 345 U.S. 1 (1953).

22 Bank Line, Limited v. United States, 163 F.2d 133 (2d Cir. 1947) ; ONeill v. United States, 79 F. Supp. 827 (E.D.Pa. 1948), rev'd on other grounds, 174 F.2d 931 (3d Cir. 1949). 23 United States v. Watkins, 67 F. Supp. 556 (S.D.N.Y. 1946). 
ernment to withhold information on the theory that by allowing suit the government has waived its privilege of non-disclosure. ${ }^{24}$

The third situation, undoubtedly the most far-reaching, is where information is withheld during the course of an administrative proceeding. The instances most typically observed follow.

\section{Failure to provide adequate notice}

In many cases, the failure of an agency to furnish the aggrieved party an adequate statement of the charges or issues presented seriously impairs the preparation of his case. Without such a statement he has hardly a fair opportunity to gather evidence, procure witnesses, and amass other relevant material to support his position.

No particular formality of pleading is required as long as the party is afforded adequate opportunity to prepare. ${ }^{25}$ However, there is hittle authority to indicate what notice will afford such an opportunity. A strict rule was established in Parker v. Lester, ${ }^{26}$ where the Coast Guard had denied clearance to a seaman who wished to work on merchant marine vessels. Accompanying the denial was a letter informing him of the "general basis" of the action. The district court declared the denial invalid and enjoined any further action by the Coast Guard until the party was furnished a bill of particulars, "to be worded with such specificity as to afford the seaman reasonable notice" of the charges, subject to the discretion of the agency to withhold such information as might be deemed confidential for security reasons. On appeal, the circuit court held that all the adverse evidence must be made available and amended the lower court's order by striking the discretionary privilege of the agency to withhold security information.

The failure to furnish a bill of particulars is not always prejudicial. In some cases, the charges and issues to be determined may be known to the party without detailed notice from the agency. ${ }^{27}$ Where hearings are lengthy the party may be given ample notice during the course of the proceedings and, where this is not sufficient, he may be granted a continuance. ${ }^{28}$

\section{Failure to disclose part or all of the adverse evidence}

The position of the party at a hearing in which he is never informed of the adverse evidence is a disturbing one. About the most he can do is inake a general denial. If he is fortunate enough to outguess the agency as to the basis and nature of the adverse evidence, he may be able to present a successful defense. This is, however, highly unlikely where the evidence is drawn from a multitude of sources over a long period of time. The position of such a party was forcefully described in

24 See, e.g., Bank Line, Limited v. United States, 163 F.2d 133 (2d Cir. 1947) (government as a litigant treated like any other private party).

Another, and considerably broader, theory was suggested in United States v. Watkins, 67 F. Supp. 556, 561 (S.D.N.Y. 1946), where the court placed its decision on the public pohicy ground that "a person should not be deprived of his hiberty without giving him an opportunity to have access to material which might exculpate him."

A seemingly well established exception to this rule is where the subject matter of the information concerns military secrets. United States v. Reynolds, 345 U.S. 1 (1953); see note 48 infra.

25 Kuhn v. CAB, 183 F.2d 839, 841 (D.C. Cir. 1950); see generally Davis, Admavistrative LAW $\$ 80$ (1951).

26 227 F.2d 708 (9th Cir. 1955).

${ }^{27}$ See, e.g., NLRB v. MacKay Radio \& Telegraph Co., 304 U.S. 333 (1938); Moog Industries v. FTC, 238 F.2d 43 (8th Cir. 1956).

28 Kuhn v. CAB, 183 F.2d 839 (D.C. Cir. 1950). 
Boudin v. Dulles, ${ }^{29}$ where the court held unconstitutional a procedure for granting passports which allowed the use of undisclosed evidence: ${ }^{30}$

\begin{abstract}
How can an applicant refute charges which arise from sources, or are based upon evidence, which is closed to him? What good does it do him to be apprised that a passport is denied him due to associations or activities disclosed or inferred from State Department files even if he is told of the associations and activities in a general way? What files? What evidence? Who made the inferences? From what materials were those inferences made?
\end{abstract}

The position of the court on review is equally difficult. Unless the evidence is on the record it is impossible to determine whether the action was justified or whether, in fact, there was any evidence at all. This is always the case where none of the adverse evidence is disclosed. But even where part has been revealed, whatever deficiency exists could always be met by the assertion that undisclosed evidence known only to the administrator justifies the result. ${ }^{31}$

\title{
Failure to state findings and conclusions
}

Even where the party knows the charges and the adverse evidence, he may still be prejudiced if not informed of the issues to be decided. In the second Morgan case $^{32}$ the Secretary of Agriculture fixed maximum rates in stockyards on a record including thousands of pages of testimony and numerous exhibits compiled at the hearings. The Supreme Court held that it was a violation of due process for the government to make its decision without according any reasonable opportunity to the party to know the claims of the agency and to contest them. Normally, this deficiency is satisfied by supplying the party with a statement of findings of fact and conclusions of law which, if given before the final decision, allows the party the opportunity to challenge on oral argument. But even if given with the final decision, the party may still contest them on petition for re-hearing or appeal.

It has been further held that a party is entitled to examine the hearing officer's report to the agency to enable him to contest the recommendations and arguments of the hearing examiner to the deciding body. ${ }^{33}$

\section{ANALYSIS AND RECOMMENDATIONS}

When called upon to review an adjudicatory action of an administrator based on undisclosed evidence, a court must reconcile two competing interests. On the

29136 F. Supp. 218 (D.D.C. 1955), rev'd on other grounds, 235 F.2d 532 (D.C. Cir. 1956).

$30 \mathrm{Id}$. at 221.

31 ICC v. Louisville \& N.R.R., 227 U.S. 88, 93 (1913); United States v. Baltimore \& O.S.W.R.R., 226 U.S. 14 (1912).

One of the few situations where a court was able to cope successfully with this problem is revealed by United States ex rel Fong Foo v. Shaughnessy, 234 F.2d 715, 719 (2d Cir. 1955). The plaintiff was appealing from a denial of a stay of deportation. The court noted that the Attorney General found that the alien would not be subject to physical persecution if deported. But the court took judicial notice "of the ruthless behavior of the Communist governments in China" and held that the administrator's finding was arbitrary and capricious. The court then continued: "If the officer who made the finding rebied upon information in the Department's files, . . should not that information have been put in the administrative record, absent a statement ... that the disclosure 'would be prejudicial to the public interest, safety, or security'?"

82 Morgan v. United States, 304 U.S. 1 (1938).

33 Gonzales v. Umited States, 348 U.S. 407, 415 (1955): " [T] before the Appeal Board imcludes the right to file a meaningful statement, one based on all the facts in the file and made with an awareness of the recommendations and arguments to be countered." Accord, Mazza v. Cavicchia, 15 N.J. 498, 105 A.2d 545 (1954). 
one hand is the interest of the public in secrecy, such as in matters involving national security; on the other is the interest of the individual in fair procedure. The problem is further complicated by the diversity of situations in which such practices may occur. When a Mr. Mezei presents himself to the Immigration Service for admittance to the United States, is lie entitled to the same procedural protections as a defendant in a prosecution for violation of the Internal Security Act? Must the government provide the same procedural considerations in discharging Miss Bailey as it does in revoking the license of a radio broadcaster?

The traditional approach in answering these questions has been to categorize the interest of a party as either a "right" or a "privilege". In this context, "privilege" indicates those situations where the party is considered to be seeking some benefit or gratuity which the government has power to grant or withhold as it sees fit. $^{34}$ When the party falls within this category it is usually said that since there is no right to receive the action, the party is entitled to no due process protections. Within this group have fallen applicants for licenses, ${ }^{35}$ applicants for passports, ${ }^{36}$ entering aliens, ${ }^{37}$ and government employees. ${ }^{38}$

In several areas, on the other hand, the courts have declared the party's interest to be a right. In these cases, although the party may not delve into all agency files or see all the investigators' reports, ${ }^{39}$ he is entitled to have all the evidence upon which the decision is based spread in the record. ${ }^{40}$ The justification given is that full disclosure of all the adverse evidence is an indispensable requisite of a fair hearing. ${ }^{41}$

The line between situtations of privilege and those of right is hazy, if not indeed indistinguishable; and the label adopted often depends on the sanctions to be applied rather than on any inherent characteristics of the terms. For instance, the issuance of passports was originally considered a matter of executive grace, but the importance of a passport in allowing freedom of travel was later considered justification for requiring that the government accord full disclosure of evidence when denying the passport. ${ }^{42}$ Likewise, although classifications as a conscientious

34 For discussion, see Davis, Admmanstratrve Law 246-54 (1951).

35 The privilege theory in license cases finds its greatest expression in state cases. See, e.g., Walker v. City of Clinton, 244 Iowa 1099, 59 N.W.2d 785 (1953); cases collected in Davis, Requirement of a Trial-Type Hearing, 70 HaRv. L. REv. 193, 270-73 (1956).

The Federal Courts, however, seem to have discarded the privilege theory. Ashbacker Radio Co. v. FCC, 326 U.S. 327 (1945) (application for broadcasting station); FCC v. National Broadcasting Co., 319 U.S. 239 (1943) (modification of existing license); Goldsmith v. Board of Tax Appeals, 270 U.S. 117 (1926) (application to practice before tax court); In re Los ADgeles County Pioneer Society, 217 F.2d 190 (9th Cir. 1954) (disbarment of attorney). But see dissenting opmion in In re Carter, 192 F.2d 15, 19 (D.C. Cir. 1951), where the privilege argument is invoked to support a denial of renewal of license without a hearing.

36 Miller v. Sinjen, 289 Fed. 388 (8th Cir. 1923); see 23 Ops. ATT'y GeN. 509, 511 (1901); 13 Ops. Atr'y Gen. 89, 92 (1869).

37 United States ex rel Knauff v. Shaughnessy, 338 U.S. 537 (1950); Harisiades v. Shaughnessy, 342 U.S. 580 (1952); Chinese Exclusion Case, 130 U.S. 581 (1889).

38 Bailey v. Richardson, 182 F.2d 46 (D.C. Cir. 1950), af'd per curiam by equally divided court, 341 U.S. 918 (1951).

39 United States ex rel St. Louis Southwestern Ry. v. ICC, 264 U.S. 64 (1924).

40 West Ohio Gas Co. v. Public Utilities Comm., 294 U.S. 63 (1935); ICC v. Abilene \& S. Ry., 265 U.S. 274 (1924) ; ICC v. Baltimore \& Ohio S.W.R.R., 226 U.S. 14 (1912); see cases collected in 18 A.T.R.2d 552 (1951).

41 See, e.g., NLRB v. Prettyman, 117 F.2d 786, 790 (6th Cir. 1941).

42 Boudin v. Dulles, 136 F. Supp. 218 (D.D.C. 1955), rev'd on other grounds, 235 F.2d 532 (D.C. Cir. 1956); Shachtman v. Dulles, 225 F.2d 938 (D.C. Cir. 1955); Dulles v. Nathan, 225 F.2d 29 (D.C.Cir. 1955); Bauer v. Acheson, 106 F. Supp. 445 (D.D.C. 1952); see Davis, $R e-$ quirement of a Trial-Type Hearing, 70 HaRv. L. REv. 193, 259-62 (1956); Jaffe, The Right to Travel: The Passport Problem, Foreign Affairs, Oct. 1956, pp. 17, 22. 
objector is only a matter of grace, ${ }^{43}$ the court requires that the registrant be furnished with a fair résumé of the adverse evidence before allowing imprisonment for failure to submit to induction. ${ }^{44}$ Whatever the merits of the shorthand privilege-right terminology, it produces a crude form of justice; the privilege argument too often leads to a denial of procedural protections.

What then is the basis for determining procedural protections? The basic premise of due process is that everyone is entitled to protection against arbitrary governmental action. Every action inust be measured by accepted and established criteria. Generally, these criteria will necessitate the determination of objective facts, that is, actual facts not colored by the feelings or opinions of the decider. It is the purpose of procedural requirements to ensure that these facts are fairly established, and that the ultimate decision rests solely upon these facts. On the other hand, where the action may be based on subjective facts, that is, on the feelings or opinions of the decider, elaborate procedural requirements are superfluous. In the latter situation, the term "privilege" may be an excellent label to describe the result, but it is not the test for a denial of procedural protections.

Assuming that we are concerned with the situation which requires a determination of objective facts, a prime requisite of fair procedure would be that all evidence upon which a decision is based be disclosed to the party. This is but one side of the total problem, however, for there may be important policy considerations which justify the abrogation of the rule against non-disclosure. For example, information involving military or other defense matters often must be withleld in interests of national security. Having recognized the propriety of non-disclosure, two further inquiries remain. How is the determination of non-disclosure to be made? And, what other measures can be used to prevent abuse $\mathrm{m}$ the use of validly withheld information?

Who should determine that information is to be withheld? Where the information has been classified before reaching the files of the agency involved in the adjudication, the agency is bound by that classification and it is beyond its power to question the reasonableness of the classification. ${ }^{45}$ But when the adjudicating agency is free from restraints of prior classification, the initial determination to withhold the information must be made by subordinate officials, for to lave all decisions cleared by the head of the agency or by a specially constituted board would impair agency efficiency. The wisdom of leaving these determinations to the untrammeled discretion of the subordinate, however, is questionable. The latent conservatism of subordinates would be a threat to reasonableness, for they are not likely to be criticized as severely for withholding information as for revealing it improvidently. ${ }^{46}$ In addition, the convenience of dispensing with bothersome

43 Dickinson v. United States, 346 U.S. 389 (1953); White v. United States, 215 F.2d 782 (9th Cir. 1954).

44 United States v. Nugent, 346 U.S. 1 (1953).

While the courts have not explicitly elevated the status of the registrant to that of having a "right", later cases have granted considerable protections. Gonzales v. United States, 348 U.S. 407 (1955) (registrant must be furnished with copy of hearing officer's report); and see Dobrenen v. United States, 235 F.2d 273 (9th Cir. 1956); Sheats v. United States, 215 F.2d 746 (10th Cir. 1954).

45 For discussion and recommendations concerning classification of information see Associatton of tHe Bar of the City of New York, The Federal Loyalty-Securtty Programs 69-72, 147 (1956); Report of the CoMmMIssion on Governarent Security 151-86 (1957).

46 "It has also been pointed out that in case of doubt the consul is taking the least risk in denying the visa ..." 7 AD. L. BuxL. 235 (1955). Perhaps this explains why over $50 \%$ of the denials or revocations of clearance in industrial security cases are reversed on appeal. See INDUStrial Personnel Securtty Review Program, 1st Annual Report 30-31 (1956). 
problems of proof may present a strong temptation to withhold information. ${ }^{47}$ And there is always a danger that the "confidential" label will be used to shield a personal or political bias. ${ }^{48}$ Thus, a protest procedure whereby the injured party may obtain review of the classification seems necessary.

Some feel that review by the head of the agency, culminating in a personal certification that disclosure would be detrimental to the public interest, would be adequate. ${ }^{48}$ This would undoubtedly correct some of the abuses suggested above, and at least lessen the bias toward illegitimate aims. ${ }^{\mathbf{5 0}}$

However, in many respects courts would seem better suited to perform the function of review. An in camera review in conference with government attorneys or other officials could adequately protect government interests; ${ }^{51}$ and, at the same time, the independent judicial examination would tend to counterbalance the administrative bias. ${ }^{52}$ The mam objection is that the judges presumably would have

47 See testimony of Almanza Tripp, an immigration official, before the Senate Subcommittee on Immigration on the problem of admission of entering aliens: "Now . . . where central registry contains something derogatory, ... I do not believe we should make a finding of admissibility until it has been disproved. But the evidence that they had in central registry would not be sufficient for our Service to exclude by the normal board of special-inquiry proceedings because those proceedings must be conducted in a manner in which they could not be subject to attack in a court of the United States." Hearings before the Subcommittee on Amendments to the Displaced Persons Act, Senate Committee on the Judiciary, 81st Cong., 1st and 2d Sess. 665, quoted in Shaughnessy v. Mezei, 345 U.S. 206, 221, n.4 (1953) (dissenting opinion). Cf., In the Matter of Conner, 6 PIKE \& FISCBER AD. L. DEC. (2d ser.) 743 (1956) (U.S. Civil Service Comm.), where the agency refused to disclose statements of witnesses in a Hatch Act proceeding.

48 "A great danger resulting from this necessary practice of delegating within the agency the powers of the agency heads is that decision is often made by an employee whose compelling personal interest is to make such a determination as he thinks will please his employer, in the hope of obtaining promotion." CoOper, AdMINISTRATtve AGENCIES AND TEE CouRTS 49 (1951).

"[A]ll too often the actual test for security clearance has been: 'What will McCarthy think if he finds out about this one?" "Green, Book Review, 44 Caxr. L. Rev. 805, 807 (1956); "[I]f the executive branelı has a sorry record on a loyalty program whose procedures give less opporturity to the accused than to a common felon, the explanation lies in a pusillanimous attitude to Congress ...." Long, Bureancracy and Constitutionalism, 46 Am. Pox. Scr. Rev. 808, 817 (1952). See remarks of Rep. Dawson, 99 Conc. Rec. 7488 (June 27, 1953) (suggests Defense Department used classified information for pohtical purposes); Newman \& Keaton, Congress and the Faithful Execution of Laws-Should Legislators Supervise Administrators?, 41 CAITE. L. REv. 565, 594 (1953).

49 In Jay v. Boyd, 351 U.S. 345, 371 (1956), Justice Frankfurter, dissenting, argued that Congress had left it to the Attorney General to square with his conscience the use of undisclosed information in denying suspension of deportation and it was improper for him to delegate this duty.

See Assoctation of the Bar of the City of New Yorz, The Federal Loyalty-Security Prograrr 174 (1956) (recommends certification by head of agency); Mankiewicz, Mangum, \& Moody, The Federal Loyalty-Security Program: A Proposed Statute, 44 Carr. L. Rev. 72, 84 (1956) (reconmmends affidavit by the Attorney General).

${ }_{50}$ As some indication of adninistrative consciences, it should be observed that both Mr. Mezei and Mrs. Knauff were later granted hearings and, ultimately, admission to the United States even though the Supreme Court had refused judicial aid. For the sequel of Mr. Mezei, see Davis, The Requirement of a Trial-Type Hearing, 70 HARv. L. REv. 193, 251 (1956); as for Mrs. Knauff, see In re Knauff, 1 PIKE \& FISCBER Ad. L. Dec. (2d ser.) 639 (1951).

51 However, it has been reported that a federal judge decided that the national security could not be safeguarded even in secret session where the action was for compensation by the inventor of a top secret device involving military matters. See San Francisco Chronicle, Apr. 24, 1957, p. 9, col. 1 .

52 The use of an in camera review has been tried by several federal courts, but the government has usually refused to submit the withheld evidence. See, e.g., Petrowicz v. Holland, 142 F. Supp. 369 (E.D.Pa. 1956); United States v. Watkins, 67 F. Supp. 556 (S.D.N.Y. 1946). 
to be cleared for security purposes. Those strongly in favor of protecting the individual's rights might feel that this is not too great a burden to impose. ${ }^{63} \mathrm{How}-$ ever, such a procedure is more than just awkward; it might prove impracticable. Judges who were not cleared could hardly be discharged, ${ }^{54}$ and yet it is extremely doubtful that cases involving security matters could be channeled only to judges who had been cleared. ${ }^{55}$ Thus certification by the head of the agency appears the most probable solution in view of the lack of any practicable alternative.

What measures could be adopted to prevent abuse in the use of validly withheld evidence? The aggrieved party's handicap in the face of undisclosed evidence may be alleviated by supplying him with the kind of résumé of the evidence now employed in draft cases ${ }^{58}$ The difficulty in such a device is in determining whether the résumé was a fair one, and several courts have demanded that the government submit the undisclosed evidence for an in camera examination to verify the fairness of the résumé. ${ }^{57}$

By non-disclosure, the substance of the information has been removed, so to speak, from purgation in a hearing. It is necessary for the administrators making or reviewing the decision to consider the evidence in the light of the handicap of the party in contesting it. ${ }^{58}$ Here again the problem finds an analogy in present practice, for the reliability of hearsay evidence must be determined in a similar manner by considering all the circumstances, mcluding supporting and opposing evidence, if any..$^{59}$

Finally, in some situations nothing less than full disclosure may be required.

Justice Jackson, dissenting in Shaughnessy v. Mezei, 345 U.S. 206, 228 n.9 (1953), commented on the lower court's attempt to have an in camera review (101 F. Supp. 66, 67, 70 (S.D.N.Y.1951)) and suggested that this would still not be sufficient to satisfy the party's right to cross-exammation or to introduce counter-evidence. In Jencks v. United States, 353 U.S. 657 (1957), the Supreme Court specifically disapproved the practice of submitting nonprivileged government documents to the trial judge for his determination of relevancy and materiality because only the defense was adequately equipped to determine their effective use.

However, several courts have refused to require in camera proceedings. Shaughnessy v. Mezei, 345 U.S. 206, 212 (1953) ("[I]t is not within the province of any court . . . to review a determination of the political branch of the Government."); Dayton v. Dulles, 146 F. Supp. 876, 882 (D.D.C. 1956) ("Nor can courts sit in canesa in order to be taken into executive confidences.").

53 "[A] Court which abdicates its mherent function of determining the facts upon which the admissibility of evidence depends will furnish to bureaucratic officials too ample opportunities for abusing the privilege." WIGMORE, EvIDENCE \& 2379, at 799 (3d ed. 1940).

$5 \pm$ The removal of federal judges can only be accomplished by impeachment proceedings. See Haynes, Setection and Tenure of Judges 19 (1944).

55 While it is conceivable that failure to pass a security check might be made cause for disqualification (see Marquette Cement Mfg. Co. v. FTC, 147 F.2d 589 (7th Cir. 1945)), a related obstacle would probably be the reluctance of the judiciary itself to submit to such a selection plan.

56 See cases cited in note 42 supra.

${ }^{57}$ See, e.g., United States v. Evans, 115 F. Supp. 340 (D.C. Conn. 1953).

58 Such cautionary instructions are now embodied in some agency regulations. See, e.g., Industrial Personnel Security Review Regulation, 32 C.F.R. 67.4-6(b) (Supp. 1957): "The Board will take into consideration the fact that the person concerned may have been handicapped in his defense by the non-disclosure to him of classified information or by his lack of opportumity to identify or cross-examine persons constituting sources of information. Accordingly, it will weigh each item of derogatory information carefully in the hight of its recency and relative seriousness, the amount and quality of supporting evidence, the attendant circumstances, whether the item was given under oath or affirmation, whether or not it is relevant to the Statement of Reasons, and whether or not the person concerned has had an opportunity to rebut it." 
When the punishment to be imposed far outweighs the interest in non-disclosure, the government inay be forced to choose between revealing the evidence and foregoing success in the action..$^{60}$

The procedures suggested are neither unusual nor new. They need only be extended into areas which are as yet unprotected. The aim of fair procedure is not to prevent all mistakes or injustices, but rather to prevent unreasonable actionaction so far removed from reasonableness as to verge on arbitrariness. The government, as well as the individual, has an interest in seeing that the administrative process operates fairly upon the individual affected..$^{61}$

David D. Walkley

59 See Davis, The Residuum Rule in Administrative Law, 28 Rockx Mr. L. REv. 1 (1955). 60 See cases cited in notes 16 and 22 supra.

61 "Let it not be overlooked that due process of law is not for the sole benefit of an accused. It is the best insurance for the Government itself against those blunders which leave lasting stains on a system of justice but which are bound to occur on ex parte consideration [citing Knauff v. Shaughnessy, 338 U.S. 537 (1950) as an illustration]." Shaughnessy v. Mezei, 345 U.S. 206, 224-25 (1953) (Jackson, J., dissenting). 